\title{
Ex Vivo Evaluation of Endodontic Retreatment Using Four Rotary File Systems and Hand Hedstrom Files in the Removal of Gutta-percha and MTA-based Salicylate Resin Sealer
}

\author{
Nerulgundi M Dhanyakumar ${ }^{1}$, Vasundhara Shivanna ${ }^{2}$, Sushant Sharma ${ }^{3}$
}

\begin{abstract}
Objectives: The aim of this study was to compare and evaluate the efficacy of rotary ProTaper retreatment (PTR) files, ProTaper universal (PTU) files, ProTaper next (PTN) file system, Mtwo retreatment (Mtwo R) files, and hand Hedstrom files in the removal of filling materials from the root canal system of extracted human mandibular first premolars.

Materials and methods: Seventy-five human mandibular first premolars were collected, stored, and cleaned. Standardization of all specimens was done to $15 \mathrm{~mm}$ length. All specimens were prepared upto F3 size using the PTU file system and obturated with F3 gutta-percha using an mineral trioxide aggregate (MTA) fillapex sealer. After coronal sealing, all teeth were stored for 1 week and then divided into five groups of 15 teeth each based on the retreatment file system used: group I-Hedstrom files, group II—PTR, group III—PTU, group IV—PTN, and group V-Mtwo R. Time taken for retreatment in each group was noted. After retreatment, all teeth were longitudinally sectioned, imaged under stereomicroscope, and scored. Data analysis was done using one-way analysis of variance and Tukey post hoc test.

Results: ProTaper retreatment files showed significantly less residual filling material in the coronal third, whereas PTN files showed significantly less residual filling material in the middle and apical third as compared with other file systems. The PTN file system took significantly less time in removing root filling material as compared with other file systems.

Conclusion: None of the file systems showed complete removal of root filling material after retreatment. ProTaper retreatment files were most efficient in the coronal third, whereas PTN files were most efficient in the middle and apical third. ProTaper next took the least retreatment time. Clinical significance: Irrespective of the file system used, root filling material is left behind, which may lead to failure of the treatment, and so an efficient retreatment file system is required.

Keywords: Hedstrom files, Mineral trioxide aggregate fillapex, Mtwo retreatment, ProTaper next, ProTaper retreatment, ProTaper universal, Retreatment. CODS Journal of Dentistry (2018): 10.5005/jp-journals-10063-0038
\end{abstract}

\section{INTRODUCTION}

Endodontic failure can occur because of various reasons such as persisting bacteria, incomplete filling of root canals, overobturation, leakage through poor coronal seal, missed canals, and procedural errors. ${ }^{1}$

A nonsurgical method of retreatment comprises removing the root filling material followed by effective cleaning, shaping, and reobturation. It will regain the health of the periapical tissues. ${ }^{2}$ Complete removal of this root filling material during retreatment is important because the remnants prevent the irrigating solutions from contacting the root canal walls. ${ }^{3}$

Gutta-percha in conjunction with a sealer is the standard obturating material. ${ }^{4}$ Various methods have been employed for removing the obturating material such as mechanical instrumentation with hand files, use of heated pluggers, ultrasonics, and rotary systems. ${ }^{5}$

ProTaper retreatment (PTR) files (Dentsply Maillefer) comprise D1, D2, and D3, which remove the gutta-percha from the coronal, middle, and apical third of the root canals. The size of D1 is 30 with taper of 9\%, D2 is 25 with taper of $8 \%$, and D3 is 20 with taper of 7\%. ${ }^{6}$

ProTaper universal (PTU) rotary file system (;Dentsply Maillefer) comprises Sx, S1, and S2 as the shaping files and F1, F2, and F3 as the finishing files. ${ }^{7}$

ProTaper next (PTN) rotary file system (Dentsply Maillefer) comprises $\mathrm{X} 1, \mathrm{X} 2, \mathrm{X} 3, \mathrm{X} 4$, and $\mathrm{X} 5$. The size of $\mathrm{X} 1$ is 17 with 0.04 taper; $X 2$ is 25 with 0.06 taper; $X 3$ is 30 with 0.75 taper; $X 4$ is 40 with \begin{tabular}{l}
\hline \hline${ }^{1-3}$ Department of Conservative Dentistry and Endodontics, College of \\
Dental Sciences, Davangere, Karnataka, India \\
Corresponding Author: Nerulgundi M Dhanyakumar, Department of \\
Conservative Dentistry and Endodontics, College of Dental Sciences, \\
Davangere, Karnataka, India, Phone: +91 6280027737, e-mail: \\
sushant13jan@gmail.com
\end{tabular}

How to cite this article: Dhanyakumar NM, Shivanna V, Sharma S. Ex Vivo Evaluation of Endodontic Retreatment Using Four Rotary File Systems and Hand Hedstrom Files in the Removal of Gutta-percha and MTA-based Salicylate Resin Sealer. CODS J Dent 2018;10(2):29-34.

Source of support: Nil

Conflict of interest: None

0.06 taper; and X5 is 50 with 0.06 taper. They are made of M-wire technology. ${ }^{8}$

Mtwo retreatment (Mtwo R) file system (VDW) comprises R1 and $\mathrm{R} 2$. The size of R1 is 15 with 0.05 taper and R2 is 25 with 0.05 taper. They have two cutting edges and cause effective cutting of dentin. ${ }^{9}$

Mineral trioxide aggregate (MTA) fillapex is an MTA-based salicylate resin comprising MTA, natural resin, salicylate resin, bismuth oxide, and silica nanoparticles. It has advantages of biocompatibility, biomineralization, and antibacterial effects. ${ }^{10}$

Till date, no study has been done which has compared the PTR, PTU, PTN, Mtwo R, and Hedstrom files in the removal of guttapercha and MTA fillapex sealer from the root canals. Therefore, the

(-) The Author(s). 2018 Open Access This article is distributed under the terms of the Creative Commons Attribution 4.0 International License (https://creativecommons. org/licenses/by-nc/4.0/), which permits unrestricted use, distribution, and non-commercial reproduction in any medium, provided you give appropriate credit to the original author(s) and the source, provide a link to the Creative Commons license, and indicate if changes were made. The Creative Commons Public Domain Dedication waiver (http://creativecommons.org/publicdomain/zero/1.0/) applies to the data made available in this article, unless otherwise stated. 
aim of this study was to compare the efficacy of PTR, PTU, PTN, Mtwo R, and Hedstrom files in the removal of gutta-percha and MTA fillapex sealer from the root canals.

\section{Materials and Methods}

This study was conducted in the Department of Conservative Dentistry and Endodontics with the help of the Department of Oral Pathology and MicroBiology, College of Dental Sciences, Davangere.

\section{Selection and Preparation of Teeth}

Seventy-five extracted human mandibular premolars were collected from the Department of Oral and Maxillo facial Surgery, College of Dental Sciences, Davangere. All teeth were collected and stored in normal saline at room temperature followed by immersion in $5.25 \%$ sodium hypochlorite for 15 minutes for disinfection.

\section{Working Length Determination}

All the specimens were decoronated to the level of cementoenamel junction by using diamond disk to standardize all root lengths to be $15 \mathrm{~mm}$. A $15 \mathrm{~K}$ file was used to create the apical patency. Patency was confirmed when the file was seen at the apex. From this length, $1 \mathrm{~mm}$ was subtracted to estimate the working length.

\section{Cleaning and Shaping}

Mechanical preparation was done till F3 size in all the specimens by using the PTU rotary file system. Five milliliters of $5.25 \%$ sodium hypochlorite was used to irrigate between each instrument change. Cleaning of all the instruments was done after each use. Each file system was discarded after being used in eight canals.

\section{Obturation}

Before obturation, all the specimens were dried using paper points. F3 gutta-percha along with the MTA fillapex sealer was used for obturating the root canals. Postoperative radiographs were taken in the buccolingual and mesiodistal direction to confirm the quality and the apical extent of the root canal filling. After obturation, the root canal orifices of all the specimens were sealed using glass ionomer cement.

\section{Storage}

After the postobturation sealing of root canal orifices, all the specimens were stored at $37^{\circ} \mathrm{C}$ with $100 \%$ humidity so that the sealer in all the teeth can set completely.

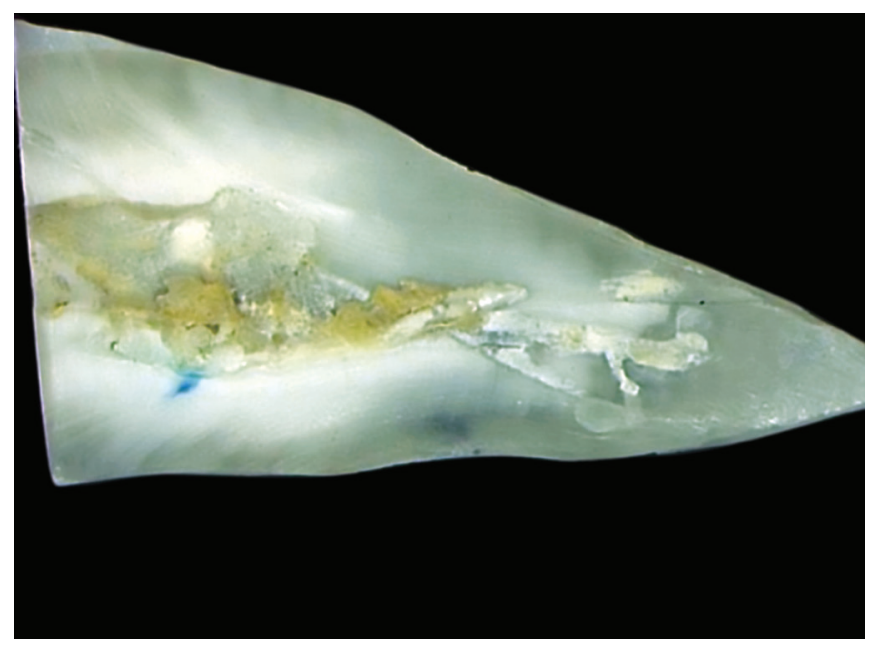

Fig. 1: Group I (Hedstrom files)

\section{Retreatment}

All the 75 specimens were divided equally into five groups of 15 teeth each depending on the retreatment protocol.

$$
\text { Group I: } n=15 \text { (Control) }
$$

The root filling material in the coronal third was removed using gates glidden drills of size 1, 2, and 3 followed by the removal from the middle and the apical portions of the root canals using hand Hedstrom files of size 30, 25, and 20 in a circumferential motion (Fig. 1).

\section{Group II: $n=15$ (PTR)}

The root filling material was removed from the coronal, middle, and apical third of the root canals using D1, D2, and D3 files of the rotary PTR file system operated at the speed of $300 \mathrm{rpm}$ and $3 \mathrm{~N} \mathrm{~cm}$ torque (Fig. 2).

\section{Group III: $n=15$ (PTU)}

The root canal filling material was removed using F1, F2, and F3 of the rotary PTU file system operated at $300 \mathrm{rpm}$ and $3 \mathrm{~N} \mathrm{~cm}$ torque (Fig. 3).

\section{Group IV: $n=15$ (PTN)}

The root canal filling material was removed using $X 1, X 2$, and $X 3$ of the rotary PTN file system operated at $300 \mathrm{rpm}$ and $3 \mathrm{~N} \mathrm{~cm}$ torque (Fig. 4).

\section{Group V: $n=15$ (Mtwo R)}

The root canal filling material was removed using gates glidden drills of size 1, 2, and 3 from the coronal third followed by using Mtwo R1 file and R2 file to the working length employing the simultaneous technique. Brushing action with lateral pressing motion was used while instrumenting with Mtwo R files. Slight apical pressure was used for the progression of the files in the root canals (Fig. 5).

Between each instrument change, irrigation was done using saline. Retreatment was accepted to be complete till no filling material could be removed from the root canals and the working length was reached.

Additionally, total time taken for the complete removal of the root filling material was recorded using the stop watch. The same operator recorded the time taken to complete retreatment in each group.

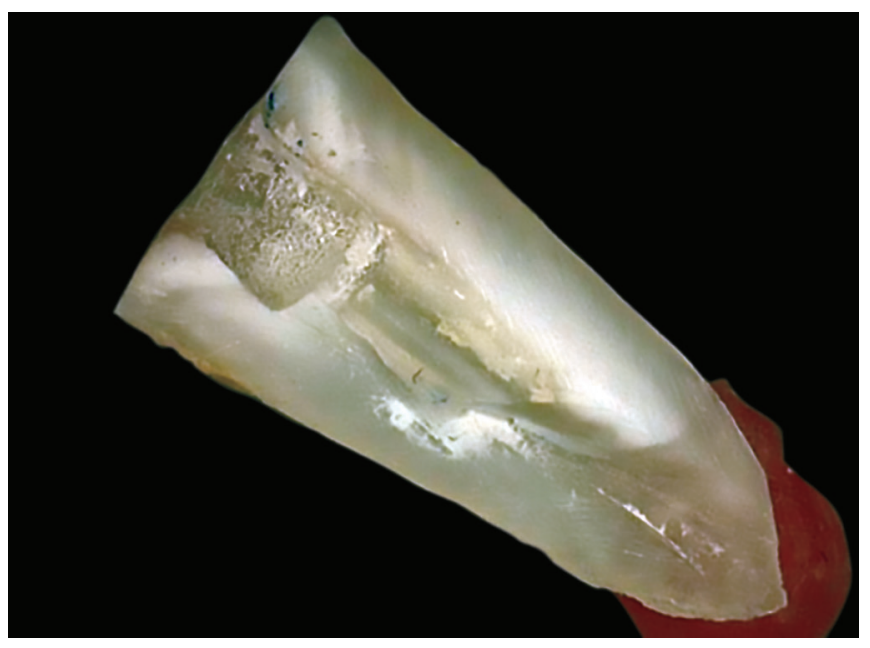

Fig. 2: Group II (ProTaper retreatment files) 


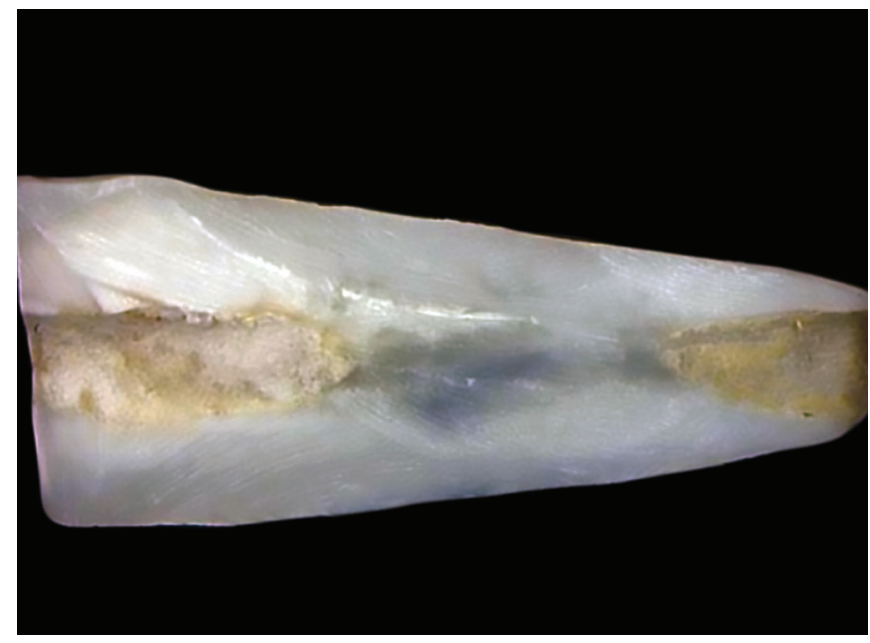

Fig. 3: Group III (ProTaper universal files)

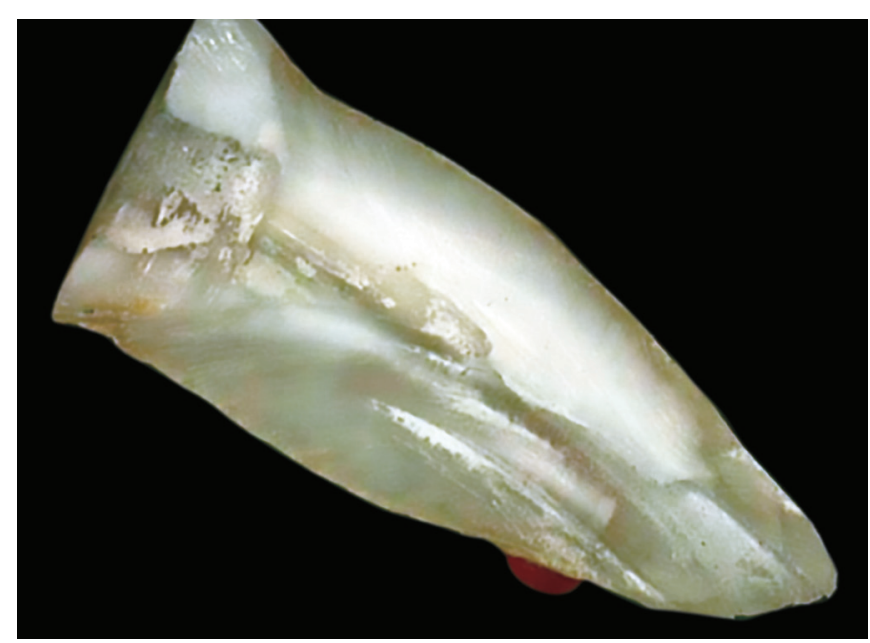

Fig. 5: Group V (Mtwo retreatment files)

\section{Assessment of Retreatment}

All the teeth were longitudinally grooved in the buccolingual direction with the diamond disk, and chisel was used to split the teeth into two halves after grooving. Both the halves of each specimen was observed under the stereomicroscope, photographed, and assessment of the residual filling material in coronal, middle, and apical third was done. The ratio between the residual root filling material and the total root canal area was calculated and expressed as a percentage using Image Analysis Software. Scoring criteria suggested by Somma et al. ${ }^{11}$ were used for assessing root filling residuals.

- Score 0: 0-25\% of dentinal surface covered with residual root filling material.

- Score 1: 25-50\% of dentinal surface covered with residual root filling material.

- Score 2: 50-75\% of dentinal surface covered with residual root filling material.

- Score 3: 75-100\% of dentinal surface covered with residual root filling material.

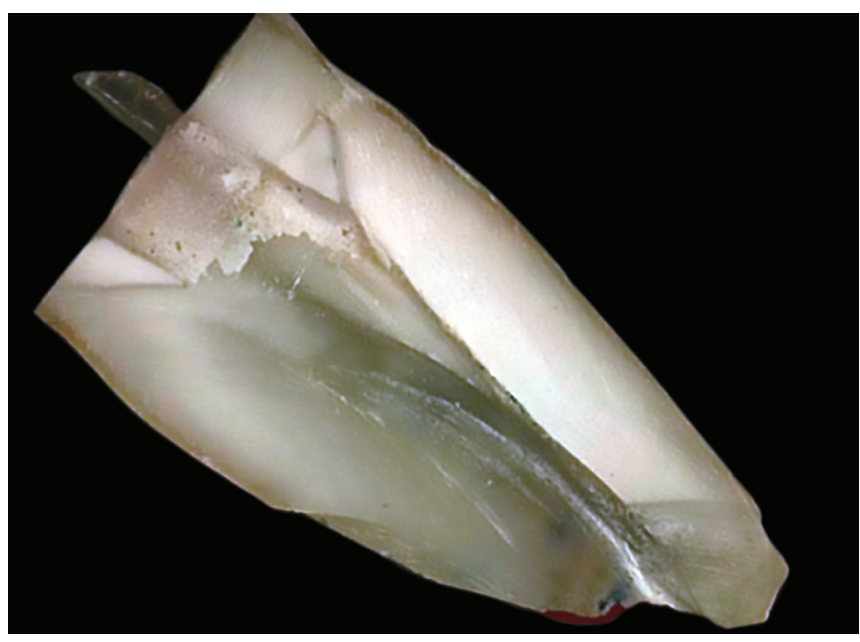

Fig. 4: Group IV (ProTaper next files)

\section{Statistical Analysis}

Data were analyzed using IBM SPSS Statistics, Version 22 (IBM Corp, Armonk, NY, USA). Variables in the amount of residual root filling material at different tooth sections were compared in each group using repeated measures analysis of variance (ANOVA) followed by Bonferroni post hoc test. One-way ANOVA was used to compare the amount of residual root filling material and retreatment time between the study groups. $p$ value $<0.05$ was considered as statistically significant.

\section{Results}

Table 1 shows comparison of the amount of residual filling material: in the coronal third, the PTR file system was most efficient in removing the residual root filling material from the root canals, followed by Mtwo R files, PTU files, Hedstrom files, and PTN file system. There was statistically significant difference between all the groups. The descending order of efficiency of various file systems is as follows:

Group II > Group V > Group III > Group I > Group IV.

In the middle and apical third, the PTN file system was most efficient in removing residual root filling material from the root canals, followed by PTU files, PTR files, Mtwo R files, and least efficient were Hedstrom files. There was statistically significant difference between all the groups. The descending order of efficiency of various file systems is as follows:

Group IV > Group III > Group II > Group V > Group I.

Table 2 shows comparison of the retreatment time:

PTN file system took the least time removing residual root filling material followed by Mtwo R files, PTR files, and PTU files, and maximum time was taken by Hedstrom files. Descending order of time taken for retreatment is as follows:

$$
\text { Group I > Group III > Group II > Group V > Group IV. }
$$

\section{Discussion}

The causes of the failure of the root canal treatment can be insufficient cleaning, shaping and obturation, persistent infection, and loss of coronal seal after root canal treatment. The result of all the causes in leakage and contamination by bacteria. ${ }^{12}$ 
Table 1: Comparison of residual root filling material among study groups

\begin{tabular}{|c|c|c|c|c|c|c|c|c|}
\hline & \multirow[b]{2}{*}{ Study groups } & \multirow[b]{2}{*}{$n$} & \multirow[b]{2}{*}{ Mean } & \multirow[b]{2}{*}{$S D$} & \multirow[b]{2}{*}{ Minimum } & \multirow[b]{2}{*}{ Maximum } & \multicolumn{2}{|c|}{ ANOVA } \\
\hline & & & & & & & $F$ & $p$ value \\
\hline \multirow[t]{5}{*}{ Coronal } & Group I & 15 & 0.70 & 0.05 & 0.60 & 0.79 & 449.78 & $<0.001^{*}$ \\
\hline & Group II & 15 & 0.18 & 0.04 & 0.11 & 0.24 & & \\
\hline & Group III & 15 & 0.39 & 0.04 & 0.34 & 0.50 & & \\
\hline & Group IV & 15 & 0.81 & 0.06 & 0.70 & 0.90 & & \\
\hline & Group V & 15 & 0.38 & 0.04 & 0.30 & 0.45 & & \\
\hline \multirow[t]{5}{*}{ Middle } & Group I & 15 & 1.44 & 0.08 & 1.30 & 1.56 & 1380.58 & $<0.001^{*}$ \\
\hline & Group II & 15 & 0.61 & 0.03 & 0.55 & 0.66 & & \\
\hline & Group III & 15 & 0.45 & 0.05 & 0.35 & 0.52 & & \\
\hline & Group IV & 15 & 0.09 & 0.03 & 0.04 & 0.15 & & \\
\hline & Group V & 15 & 0.84 & 0.06 & 0.75 & 0.93 & & \\
\hline \multirow[t]{5}{*}{ Apical } & Group I & 15 & 1.62 & 0.08 & 1.45 & 1.74 & 1238.36 & $<0.001^{*}$ \\
\hline & Group II & 15 & 0.76 & 0.07 & 0.68 & 0.89 & & \\
\hline & Group III & 15 & 0.49 & 0.04 & 0.41 & 0.55 & & \\
\hline & Group IV & 15 & 0.14 & 0.05 & 0.05 & 0.21 & & \\
\hline & Group V & 15 & 1.04 & 0.06 & 0.96 & 1.14 & & \\
\hline
\end{tabular}

${ }^{*} p<0.05$ statistically significant; $p>0.05$. SD, standard deviation; ANOVA, analysis of variance; NS, nonsignificant

Table 2: Comparison of retreatment time among study groups

\begin{tabular}{|c|c|c|c|c|c|c|c|}
\hline \multirow[b]{2}{*}{ Study groups } & \multirow[b]{2}{*}{$n$} & \multirow[b]{2}{*}{ Mean } & \multirow[b]{2}{*}{$S D$} & \multirow[b]{2}{*}{ Minimum } & \multirow[b]{2}{*}{ Maximum } & \multicolumn{2}{|c|}{ ANOVA } \\
\hline & & & & & & $F$ & $p$ value \\
\hline Group I & 15 & 6.36 & 0.05 & 6.25 & 6.43 & 1038.82 & $<0.001^{*}$ \\
\hline Group II & 15 & 4.43 & 0.06 & 4.31 & 4.52 & & \\
\hline Group III & 15 & 5.25 & 0.08 & 5.10 & 5.36 & & \\
\hline Group IV & 15 & 3.07 & 0.20 & 2.58 & 3.20 & & \\
\hline Group V & 15 & 3.91 & 0.25 & 3.56 & 4.15 & & \\
\hline
\end{tabular}

${ }^{*} p<0.05$ statistically significant; $p>0.05$. SD, standard deviation; ANOVA, analysis of variance; NS, nonsignificant

Nonsurgical retreatment is defined as a procedure of removing the root canal filling material, accompanied by cleaning, shaping, and obturation of the root canals. The primary goal of nonsurgical retreatment is to remove the root filling material completely, establishing the working length again, and finally obturating the root canals which will help to reestablish the health of periapical tissues. $^{13}$

Decoronation of all the teeth was done to perform standardization by removing the factors such as root canal access and anatomy of tooth crown. ${ }^{9}$

MTA fillapex was used because it forms apatite-like crystalline deposits, has low film thickness, high flow rate, not adversely affected by heat, has antibacterial properties, and has the tendency to maintain relative constant release of calcium for 14 days. ${ }^{14}$

Different systems have been used for removing root canal filling material. These are stainless steel hand files, nickel titanium files, ultrasonics, and lasers. Nickel titanium rotary files have been used because they take less time than hand files, stay more centered in the canal, cause less procedural errors, have superelasticity, and produce increased taper root canal preparation facilitating efficient irrigation. ${ }^{15}$ Hedstrom files have been used because of their ability to remove gutta-percha in large pieces. ${ }^{16}$

In the present in vitro study, in the coronal third PTR files left the least residual root filling material because of the greater size and taper of D1 (30 and 0.09). MtwoR files were efficient in removing root filling material only next to PTR files because of prior use of no. 1, 2 , and 3 gates glidden drills followed by use of R2 (25 and 0.05 ) file using the simultaneous technique. ProTaper universal files were not as efficient as PTR and Mtwo R files but were better than Hedstrom files and PTN files because of size and taper of F1 file is 20 and 0.07 . Although Hedstrom files had greater size of 30 when compared with PTU, the taper is only 0.02 which was not sufficient to cause debris removal coronally. ${ }^{17}$ Moreover, manual instrumentation acts like a piston which pushes the debris more apically. ${ }^{18}$ ProTaper next files were the least efficient in removing root filling material because of the least size of 17 and taper of $0.04 .^{17}$

In the middle and apical third, PTN files were the most efficient files. Due to their offset design and swaggering motion, there is minimum engagement of the files with dentin, more space for cutting, loading, and debris auguration with lesser chances of root canal blockage. ${ }^{19}$ PTU files were the second most efficient files because of their size and taper of final F3 file of 30 and 0.09 is greater as compared with that of final D3 file of PTR with size and taper of 20 and 0.07 , final R2 file of Mtwo R with size and taper of 25 and 0.05 and final \#20 Hedstrom file with size and taper of 20 and 0.02 , respectively. ${ }^{17}$ PTR files were more effective than Mtwo $R$ files because of D1, D2, and D3 having progressive taper and lengths of 16,18 , and $22 \mathrm{~mm}$, respectively. ${ }^{2}$ Mtwo $R$ files do not use the crown down technique and because of using the single length technique, they leave more residual root filling material. ${ }^{20}$ 
The result is in accordance with the study conducted by da Silva et al., ${ }^{21}$ in which they found PTR files to be more efficient than Mtwo $R$ files because of their convex triangular cross section which makes their internal mass greater than that of Mtwo R files. Moreover, PTR files prepared greater area of root canal due to their greater taper.

ProTaper next files were the fastest in the removal of root filling material because of their offset design, resulting in their wave-like motion which helps to cut a larger envelope as compared with the file of similar size of symmetrical mass. ${ }^{22}$ Mtwo R files were the second fastest in removing root filling material because of their two cutting edges, S-shaped cross section, and pitch length increasing from their apical to coronal part. Moreover, they do not use the crown down technique as each file is taken to the working length. ${ }^{2}$ PTR files were faster than the PTU files because of the active tip of D1 which allows better penetration into gutta-percha initially and makes it easier for D2 and D3 to penetrate. ${ }^{23}$

The method of assessment of the residual filling material is also an essential parameter. Methods such as longitudinal cleavage of specimens, association of longitudinal and transverse cleavage of specimens for assessment in different root thirds, and radiographic methods have been employed. Radiographic methods were not employed because of the inaccuracies caused due to the magnification and distortion caused while attempting to represent a three-dimensional object in two dimensions. ${ }^{24}$ In this study, direct visual scoring of the images of the longitudinally cleaved teeth obtained with stereomicroscope was done as it is a simple and efficient method. ${ }^{25}$

No solvent was used for removing root filling material because solvent causes softening of root filling material which then gets packed into the irregular surfaces of root canal walls and dentinal tubules which cannot be removed. ${ }^{26}$ Moreover, retreatment time is increased on using solvent. ${ }^{27}$

\section{Conclusion}

Within the limitations of the present in vitro study, the study concludes as follows:

- None of the instrument groups could cause complete removal of root filling material from the root canals.

- ProTaper retreatment files were significantly more efficient than other instrument groups in the coronal third of the root canal due to the greatest size and taper of D1 file in the coronal third which are 30 and 0.09 and it has an active tip.

- ProTaper next files were significantly more efficient than other instrument groups in the middle and apical third of the root canal because of their offset design and swaggering motion, and they have minimal engagement with root dentin and have greater area for cutting, loading, and debris auguration.

- ProTaper next files were significantly faster than other instrument groups in complete removal of root filling material because of their offset design, they produce wave-like motion and cut a larger envelope as compared with the file of similar size of symmetrical mass.

\section{References}

1. Tabassum S, Khan FR. Failure of endodontic treatment: the usual suspects. Eur J Dent 2016;10(1):144-147. DOI: 10.4103/13057456.175682.

2. Khedmat S, Azari A, Shamshiri AR, et al. Efficacy of ProTaper and Mtwo retreatment files in removal of gutta-percha and GuttaFlow from root canals. Iran Endod J 2016;11(3):184-187. DOI: 10.7508/iej.2016. 03.007.

3. Oltra E, Cox TC, LaCourse MR, et al. Retreatability of two endodontic sealers, EndoSequence BC sealer and AH Plus: a micro-computed tomographic comparison. Restor Dent Endod 2017;42(1):19-26. DOI: 10.5395/rde.2017.42.1.19.

4. Orstavik D. Materials used for root canal obturation: technical, biological and clinical testing. Endod Topics 2005;12(1):25-38. DOI: 10.1111/j.1601-1546.2005.00197.x.

5. Shrivastava N, Shrivastava A, Bhandari M, et al. Efficacy of three different instruments for gutta-percha removal in root canal retreatment. Int J Appl Dent Sci 2018;4(2):72-75.

6. Fariniuk LF, Azevedo MD, Carneiro E, et al. Efficacy of protaper instruments during endodontic retreatment. Indian J Dent Res 2017;28(4):400-405. DOI: 10.4103/ijdr.IJDR_89_16.

7. Wu J, Lei G, Yan M, et al. Instrument separation analysis of multi-used ProTaper Universal rotary system during root canal therapy. J Endod 2011;37(6):758-763. DOI: 10.1016/j.joen.2011.02.021.

8. Troiano G, Dioguardi M, Cocco A, et al. Centering ability of ProTaper next and WaveOne classic in J-shape simulated root canals. ScientificWorldJournal 2016;2016:1606013. DOI: 10.1155/2016/1606013.

9. Kanaparthy A, Kanaparthy R. The comparative efficacy of different files in the removal of different sealers in simulated root canal retreatment- an in-vitro study. J Clin Diagn Res 2016;10(5): ZC130-ZC133. DOI: 10.7860/JCDR/2016/17731.7845.

10. Borges AH, Dorileo MCGO, Villa RD, et al. Physicochemical properties and surface morphologies evaluation of MTA Fillapex and AH Plus. ScientificWorldJournal 2014;2014:589732. DOI: 10.1155/2014/589732.

11. Somma F, Cammarota G, Plotino G, et al. The effectiveness of manual and mechanical instrumentation for the retreatment of three different root canal filling materials. J Endod 2008;34(4):466-469. DOI: 10.1016/j.joen.2008.02.008.

12. Ruddle CJ. Nonsurgical endodontic retreatment. J Calif Dent Assoc 2004;32(6):474-484.

13. Kasam S, Mariswamy AB. Efficacy of different methods for removing root canal filling material in retreatment- an in-vitro study. J Clin Diagn Res 2016;10(6):ZC06-ZC10. DOI: 10.7860/JCDR/2016/17395.7904.

14. Gad RA, Farag AM, El-Hediny HA, et al. Sealing ability and obturation quality of root canals filled with gutta-percha and two different sealers. Tanta Dent J 2016;13(4):165-170. DOI: 10.4103/16878574.195703.

15. Das $S$, Ida AD, Das $S$, et al. Comparative evaluation of three different rotary instrumentation systems for removal of gutta-percha from root canal during endodontic retreatment: an in vitro study. J Conserv Dent 2017;20(5):311-316. DOI: 10.4103/JCD.JCD_132_17.

16. Imura N, Kato AS, Hata Gl, et al. Comparison of the relative efficacies of four hand and rotary instrumentation techniques during endodontic retreatment. Int Endod J 2000;33(4):361-366. DOI: 10.1046/j.13652591.2000.00320.x.

17. Albrecht LJ, Baumgartner JC, Marshall JG. Evaluation of apical debris removal using various sizes and tapers of ProFile GT files. J Endod 2004;30(6):425-428. DOI: 10.1097/00004770-200406000-00012.

18. Kustarci A, Altunbas D, Akpinar KE. Comparative study of apically extruded debris using one manual and two rotary instrumentation techniques for endodontic retreatment. J Dent Sci 2012;7(1):1-6. DOI: 10.1016/j.jds.2011.09.011.

19. Suparna SG, Poorvi S, Sandeep D, et al. Comparison of root canal cleaning ability of ProTaper NEXT and WaveOne rotary file systemsa scanning electron microscopic (SEM) study. Endodontology 2015;27(2):124-128.

20. Tasdemir T, Er K, Yildirim T, et al. Efficacy of three rotary $\mathrm{NiTi}$ instruments in removing gutta-percha from root canals. Int Endod J 2008;41(3):191-196. DOI: 10.1111/j.1365-2591.2007.01335.x.

21. da Silva BM, Filho FB, Leonardi DP, et al. Effectiveness of ProTaper, D-Race, and Mtwo retreatment files with and without supplementary instruments in the removal of root canal filling material. Int Endod J 2012;45(10):927-932. DOI: 10.1111/j.1365-2591.2012.02051.x. 
22. Dixit K, Shivanna V, Siddheshwaran V. An ex-vivo comparison of apical extrusion of debris and working time used by three different ProTaper file systems during endodontic retreatment. IOSR-JDMS 2018;17(8):22-25.

23. Obeid MF, Elgendy AA. Efficacy of three Ni-Ti rotary systems for removal of filling materials from root canal system of extracted teeth. Tanta Dent J 2015;12(4):259-264. DOI: 10.1016/j.tdj.2015. 08.002 .

24. Yadav P, Bharath MJ, Sahadev CK, et al. An in vitro CT Comparison of gutta-percha removal with two rotary systems and Hedstrom files. Iran Endod J 2013;8(2):59-64.
25. Uzunoglu E, Yilmaz Z, Sungur DD, et al. Retreatability of root canals obturated using gutta-percha with bioceramic MTA and resin-based sealers. Iran Endod J 2015;10(2):93-98.

26. Horvarth SD, Altenburger MJ, Naumann M, et al. Cleanliness of dentinal tubules following gutta-percha removal with and without solvents: a scanning electron microscopic study. Int Endod J 2009;42(11):1032-1038. DOI: 10.1111/j.1365-2591.2009.01616.x.

27. Kfir A, Tsesis I, Yakirevich E, et al. The efficacy of five techniques for removing root filling material: microscopic versus radiographic evaluation. Int Endod J 2012;45(1):35-41. DOI: 10.1111/j.13652591.2011.01944.x. 